\title{
ZBIRKA SENTENCIJA IZ PETRISOVA I GRŠKOVIĆEVA ZBORNIKA U KONTEKSTU HRVATSKOGLAGOLJSKE REFLEKSIVNE PROZE
}

Andrea Radošević

Staroslavenski institut

Demetrova 11

HR 10000 Zagreb

aradosevic@stin.hr
UDK: 811.163.42"16"

003:811.163.42"16"

Izvorni znanstveni članak

Ur.: 2021-08-02

U radu se analizira kratka zbirka sentencija iz dvaju hrvatskoglagoljskih zbornika: Petrisova i Grškovićeva. Zbirka se većim dijelom sastoji od citata i parafraza biblijskih mudrosnih knjiga (Mudre izreke, Propovjednik, Knjiga Sirahova). Usporedbom dvaju prijepisa Zbirke iz navedenih zbornika s hrvatskoglagoljskim brevijarima utvrđuju se sličnosti i razlike u pristupu biblijskim citatima. Na više se primjera pronalaze potvrde slobodnoga odnosa prema prepisivanom tekstu, pogotovo u kompilaciji iz 16. stoljeća. Sličnosti između citata u Zbirci i nekim brevijarima, a koje ne nalazimo ni u Septuaginti, ni Vulgati, ni u parimejnicima, upućuju na mogućnost zagledanja u glagoljske brevijare tijekom prepisivanja Zbirke. Rad pridonosi poznavanju hrvatske srednjovjekovne refleksivne proze.

Ključne riječi: srednjovjekovna refleksivna proza, mudrosne knjige, zbirka sentencija, Petrisov zbornik, Grškovićev zbornik

\section{Uvod}

Glagoljašku lektiru između ostalog sačinjavali su razni religioznodidaktični tekstovi namijenjeni ponajprije poduci duhovnoga podmlatka, ali i pastve općenito. ${ }^{1}$ Služili su podučavanju ispravnome životu usklađenu s temeljnim kršćanskim vrijednostima, a svoj najsažetiji oblik takva su učenja imala u izrekama i sentencijama unesenima iz Biblije, istaknutih antičkih i srednjovjekovnih autoriteta. Zbirke izreka i moralnih sentencija u srednjem vijeku nalazimo u raznim oblicima: prepisivane su zasebno i u manjim

${ }^{1}$ E. HERCIGONJA, 1975; D. FALIŠEVAC, 1980. Navedimo samo nekoliko primjera refleksivne proze: Cvijet kreposti, Lucidar, Fiziolog. 
cjelinama, u sklopu vježbi prevođenja/prepisivanja, u svrhu podučavanja i sl. ${ }^{2}$ Taylor ih opisuje kao tekst koji iznosi prijedloge ponašanja, izrečene u kratkim parataktično oblikovanim rečenicama. ${ }^{3}$ Glavne su im karakteristike kratkoća, laka pamtljivost, jednostavna struktura i figurativan jezik, ${ }^{4}$ dok njihova najveća snaga leži u moći uvjeravanja i autoritativnoj istini. Opisujući mudrosne forme (tzv. wisdom forms) Taylor govori kako izreka i egzemplum predstavljaju krajnje stupnjeve narativnoga, pri čemu egzempl naziva najrazvijenijom mudrosnom formom. ${ }^{5}$ Dok u izrekama narativnost u potpunosti izostaje, egzempl u značenju kratke poučne priče sadrži najveći stupanj narativnosti. ${ }^{6}$ Od 13. st. zbirka sentencija, uz zbirke egzempla, razne florilegije i slično, počinje se upotrebljavati kao referentna zbirka za propovjednike. ${ }^{7}$

Zasad je poznat relativno malen broj glagoljaških refleksivnih tekstova sastavljenih većinom od moralnih izreka i sentencija. ${ }^{8} \mathrm{U}$ užu skupinu hrvatskoglagoljskih djela koja Hercigonja naziva svjetovnim moralizatorskodidaktičnim spisima, ${ }^{9}$ tj. "moralističkim sentencijama, poukama i savjetima očevih sinu za ponašanje u životu" uvršteni su Nauk sinu Vičerdovu, ${ }^{10}$ Knjige Kata mudroga te kratka zbirka moralnih sentencija. ${ }^{11}$ Vrijedi spomenuti kako su sva tri teksta sačuvana u Petrisovu, a dva u Grškovićevu zborniku. ${ }^{12}$ Moralne sentencije i pouke za dobar život čine bitan dio teksta Riči od nauka svetih otac sačuvana u Ivančićevu i Petrisovu zborniku, ${ }^{13}$ ali i Cvijeta kreposti nastala

${ }^{2}$ R. L. HARRIS, 2019, 10.

${ }^{3}$ B. TAYLOR, 1992, 19.

${ }^{4}$ B. TAYLOR, 1992, 21.

${ }^{5}$ B. TAYLOR, 1992, 21. "The sermon exemplum, with its continual recourse to the miraculous tends in the other direction, toward the benevolent example, the narrative which fulfills its sententia, revealing it as narrative result. This rhetorical propensity of the public exemplum is simultaneously thematic, an insistence on the inherent disorder of the historical world it addresses."

${ }^{6}$ Gradaciju od maksima do egzempla opisuje Ford u radu o egzemplarnim formama u djelu Disciplina clericalis. (G. FORD, 2015, 28-29)

${ }^{7}$ B. TAYLOR, 1992, 33.

${ }^{8} \mathrm{~J}$. REINHART, 2012, 222.

${ }^{9}$ E. HERCIGONJA, 1975, 393.

${ }^{10}$ Iako postoje slični tekstovi u talijanskoj književnosti (npr. sjevernotalijanski tekst Insegnamenti a Guglielmo), Reinhart je pokazao kako bi Nauk sinu Vičerdovu mogao biti čak izvorno hrvatski te da je krajem 14. ili početkom 16. stoljeća nastao u Istri. J. REINHART, 2012, 213-214; 222-223.

${ }^{11}$ R. HAZELTON, 1957, 161-163; E. HERCIGONJA, 1975, 393-394.

${ }^{12} \mathrm{U}$ tim dvama glagoljskim zbornicima sačuvano je ukupno čak 13 paralelnih tekstova što ni u kojem slučaju nije zanemariv podatak. (J. REINHART, 2012; A. RADOŠEVIĆ, 2017)

${ }^{13} \mathrm{~V}$. ŠTEFANIĆ, 1960, 367-368. 
prema traktatu Fiore de virtù (između 1310. i 1323. godine) bolonjskoga notara Tomassa Gozzadinija čiji je prijevod sačuvan u čak pet glagoljskih zbornika: Vinodolskom, Petrisovu, Ljubljanskom, Tkonskom i Grškovićevu, zatim u ćiriličnom dubrovačkom rukopisu Libro od mnozijeh razloga (1520.) i prijevodu bosanskoga franjevca Pavla Posilovića pod nazivom Cviet kriposti duhovni $i$ tilesnie prikoristan svakomu virnomu karstianinu koi ga šti često (1647., 1701.), te na kraju u latiničnom izdanju Cvijet od kriposti prikoristan dječici i svakomu vjernomu krstjaninu koji ga uzbude štiti često iz 1712. i 1756. bokokotorskoga vlastelina Krsta Mazarovića. ${ }^{14}$ Moralna poduka u tom je tekstu "posredovana diskurzivnim tehnikama poput sentencija, kontrasta, refleksija, tumačenja, izlaganja, prijekora." ${ }^{15} \mathrm{Za}$ razliku od Cvijeta kreposti u kojem se izreke i sentencije pojavljuju u sklopu tumačenja određenog pojma te u kojem većina kapitula počinje tvrdnjama srednjovjekovnih autoriteta (Ot mira piše s(ve)ti Avgustin, Piše s(ve)ti Toma da gnev, Ot lubve bližik piše prorok), u kratkoj zbirci koja je tema ovoga rada citati i njihove parafraze nižu se jedan za drugim, no oni nisu u tolikoj mjeri tematski povezani kao oni u Cvijetu kreposti. Dio Zbirke u kojima se nižu savjeti za ispravan kršćanski život na formalnoj razini može se usporediti s glagoljskim tekstom Riči od nauka s(ve)tihb o(ta)c: Ne gledâj' tvoihs dobrotb . ni zledi druzih'. Biži d'ružbu druzihs ako ni za potribu (...) Biži v'se ĉedi to e(tsb) taĉadb - ot v'sakoga huda hojen'ê ot'vrati tvoe tilo, Ivančićev zbornik, 176v-177r.

Iako Priča o premudrom Akiru sadržava moralnih pouka, izreka i aforizama, i to u svojstvu "važnoga diskurzivnog i pedagoškog sredstva", ${ }^{16}$ riječ je ipak ponajprije o srednjovjekovnom romanu. ${ }^{17}$ Naime, u srednjem vijeku nije bila rijetkost pronaći primjere intenziviranja moralne pouke na način da se,

${ }^{14}$ Više o hrvatskim prijevodima i izdanjima Cvijeta kreposti vidi u A. ZARADIJA KIŠ M. ŠIMIĆ, 2020, 61-73. U tome traktatu nalazi se mnoštvo citata antičkih autora, ali i navoda iz Biblije, između ostalog i mudrosnih knjiga. P. Knezović govori o ukupno 66 citiranih pisaca (zajedno sa Svetim pismom) i 629 izreka, dok A. Zaradija Kiš i M. Šimić navode bestijarska izvorišta teksta te arapske izvore mudroslovlja. Ispred imena autora u tome se traktatu nerijetko pojavljuje epitet mudri: mudri Platonb, mudri Tulio, mudri Sokrates, mudri Tolomei, mudri Omer i sl. Vidi P. KNEZOVIĆ, 2001; A. ZARADIJA KIŠ - M. ŠIMIĆ, 2020, 18. U Cvijetu krjeposti vrline i mane razmatraju se, i to prema Summi sv. Tome Akvinskoga, na "pamtljivim sentencijama istaknutih antičkih i srednjovjekovnih autoriteta te na životinjskim predodžbama ljudske naravi (...) po načelu kontrasta raspravlja o mudrosti i mahnitosti, pravdi i nepravdi, iskrenosti i laži, vjernosti i lukavosti, o taštini, uzdržljivosti i neumjerenosti, čednosti i požudi, te o umjerenosti." (D. GRMAČA, 2020, 38)

${ }^{15}$ D. GRMAČA, 2020, 38.

${ }^{16}$ D. GRMAČA, 2020, 39.

${ }^{17}$ V. BADURINA STIPČEVIĆ, 2015. 
primjerice u narativne i refleksivne tekstove, unose citati iz biblijskih mudrosnih knjiga koje karakterizira jezgrovito izražavanje, poučni nagovori i česte antiteze. ${ }^{18}$

Ovaj rad posvećen je kratkoj zbirci moralnih sentencija koju Hercigonja naziva malom zbirkom moralističke aforistike. Riječ je o tekstu koji se u starijem Petrisovu zborniku iz 1468. godine (dalje CPet, f. 238-239) pojavljuje kao zasebno štivo, a u Grškovićevu zborniku iz 16. st. (dalje CGršs, f. 188r-189r) kao drugi dio kompilacije (sermona) čiji se prvi dio odnosi dva Pseudo-Bernardova poglavlja. ${ }^{19}$

\section{Hrvatskoglagoljska kratka zbirka moralnih sentencija}

Zbirka moralnih sentencija koja je sačuvana u dvama glagoljskim rukopisima (CGrš, CPet) većinom se sastoji od prijevoda i parafraza biblijskih mudrosnih knjiga, točnije tekstova koje se u srednjem vijeku smatralo Salomonovim knjigama: Mudrih izreka, Propovjednika i Pjesme nad Pjesmama te Knjige Mudrosti i Siraha. ${ }^{20}$ Danas istraživači rjeđe u taj korpus uvrštavaju Pjesmu nad pjesmama. ${ }^{21}$ Izuzev navoda i parafraza citata iz mudrosnih knjiga, zbirka sadržava nekoliko citata iz ostalih dijelova Staroga i Novoga zavjeta.

$\mathrm{Za}$ razliku od nekih drugih biblijskih knjiga (poput Knjige Postanka, Psalama, poslanica Pavla apostola), one mudrosne nisu toliko često bile predmetom komentara crkvenih otaca. Njihova zamašnija egzegeza pojavljuje se, naime, tek u karolinško doba, a do toga razdoblja tumačile su se većinom u komentarima cjelokupnoga Svetoga Pisma. ${ }^{22}$ Među najranije komentare tako ubrajamo Jeronimov komentar Propovjednika, zatim tumačenje Mudrih izreka iz pera Bede Časnoga, potom Rabana Maura koji tumači Knjigu mudrosti i Siraha, zatim one genovskoga biskupa Salonijusa, Honoriusa Augustodunensisa, Bonaventure, dominikanskih autora i dr. ${ }^{23}$ Hugo iz St. Chera smatra kako su Mudre izreke, sa svojim savjetima o vrlinama i dobrom ponašanju (aktivnom životu općenito), bliske moralnoj filozofiji. Prijelaz prema kontemplativnom životu nalazi u

18 V. BADURINA STIPČEVIĆ, 2013, 3; 2015, 381; F. MAXINER, 1885, 91; A. RADOŠEVIĆ, 2017.

${ }^{19}$ A. RADOŠEVIĆ, 2017.

${ }^{20}$ G. DAHAN, 2020, 429. J. Reinhart piše kako mudrosna književnost u grčkom Starom zavjetu obuhvaća Mudre izreke, Knjigu mudrosti, Joba, Siraha i dijelove Psalama, Tobita i Baruha. $\mathrm{Na}$ latinskom u tu su književnost uključene Mudre izreke, Knjiga Mudrosti, Knjiga Sirahova i Pjesma nad Pjesmama. (J. REINAHRT, 1985, 79)

${ }^{21}$ G. DAHAN, 2020, 429.

${ }^{22}$ G. DAHAN, 2020, 430. Tako primjerice u Augustinovu djelu Scripta Sanctorum nalazimo tumačenja dijela knjiga De proverbis, De Ecclesiastico, De libro sapientiae.

${ }^{23}$ G. DAHAN, 2020, 430. 
učenjima o preziranju materijalnih stvari kojima obiluje Propovjednik, a čisti kontemplativni život u Pjesmi nad pjesmama. ${ }^{24}$ Neki pak autori, poput Jeronima, mišljenja su kako su Mudre izreke upućene djeci (početnicima), Propovjednik čovjeku na pragu odrastanja, a Pjesma nad Pjesmama savršenom čovjeku. ${ }^{25}$

Zbirka moralnih sentencija većinom sadržava starozavjetne izreke kojima se prenose savjeti o mudrom životu (strpljivost, pribranost, umjerenost) kako bi se izbjegla ludost, odnosno bezbožnost: manen človek naglo pustiv gniv, mudar že rasmotriv; budi skor slišati a kasan odgovoriti; sin mudar veselit oca, a sin manen pečal materi svoei. U njima su sadržane upute u vođenje ispravnoga odnosa prema Bogu i bližnjemu te očinske opomene koje uključuju čuvanje od oholosti, taštine, opijanja, prejedanja i drugih tjelesnih užitaka. Veći dio sentencija pojavljuje se u obliku apela, opomena te upozorenja i zapovijedi čija se učestalost povećava na kraju teksta u kojima parafrazirane i skraćene mudre izreke poprimaju zapovjedni ton: ne dai po voli misli svoei, ne pit vina mnogo, vazda razmisli konac.

Iako se u kratkoj Zbirci sentencije ne navode ni abecednim redom ni prema njihovu biblijskom redoslijedu, stječe se dojam kako nisu samo nasumično ispisane. Slično kao i u Nauku sinu Vičerdovu mogle bi se izdvojiti neke kraće tematske cjeline ${ }^{26} \mathrm{Na}$ početku Zbirke većinom se pojavljuju prijevodi starozavjetnih citata iz tzv. mudrosnih knjiga, a prema kraju su učestalije parafraze.

Struktura zbirke: Zbirka počinje kratkom cjelinom u kojoj se veliča opći pojam mudrosti prema sebi i bližnjima. Potom dolazi cjelina u kojoj se opisuje ispravan odnos prema Bogu. Jedino u CPet slijedi citat koji potiče na refleksiju o našem ponašanju evociranjem pojma pravednika i grešnika: Ako pravadni edva spaset se, a grešnik'kadê êvit'se. Naime, u mudrosnim knjigama (Mudrim izrekama, Knjizi mudrosti i Sirahu) nepravednik/bezumnik suprotstavljen je pravedniku, tj. "oni koji su vjerni zakonu su mudri, pobožni i sretni, a oni koji nisu su bezumni, ludi, bezbožni i nesretni". ${ }^{27}$ Takvim aluzijama o nesigurnosti čak i onih koji izvršavaju zapovijedi naglašava se koliko su grešnici daleko od bilo kakva spasenja. Nakon toga općenite tvrdnje izmjenjuju se sa savjetima upućenima recipijentu u drugome licu. Neke upute (npr. Manen čl(ovê)k naglo pustit'gniv, mudar že rasmotriv) stupaju u izravnu vezu s navodima iz Pavlove

\footnotetext{
${ }^{24}$ G. DAHAN, 2020, 440.

${ }^{25}$ G. DAHAN, 2020, 439.

${ }^{26}$ Taj tekst Reinhart je podijelio na 20 cjelina u kojima se iznose savjeti i opomene. (J. REINHART, 2012)

${ }^{27}$ I. MILIČIĆ, 1999, 61.
} 
poslanice Galaćanima koja u kompilaciji u CGrš povezuje Zbirku i PseudoBernardov tekst: ne podobaet nam prěti se krotkim i trplivim biti vsagda to e

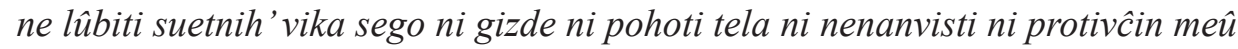
bratiû, 188r. U drugom se dijelu Zbirke antitetičkim rečenicama opreka mudrost/ ludost konkretizira suprotstavljanjem skrbi/veselja, posluha/neposluha, gnjeva/ smirenosti: Mudri sveta poslušati' i nori ga otmetaet'; Pokarai mudra, vzlubit te, a nori vznenavidit te, dai mudru krivinu i mudri budet, skaži nemu pravdu $i$ vzlubit te. Upravo se takvim suprotstavljanjem mudrog i norog ili manenog, vjernog i lažljivog, primatelj potiče da odabere stranu mudrog koji sluša Božje zapovijedi. Nakon poznatoga iskaza koji nalazimo i u drugim proznim tekstovima o strahu gospodnjem kao začelu mudrosti slijedi dio s konkretnim uputama koje predstavljaju parafraze uglavnom biblijskih citata. I dok u CPet svaka uputa sadržava zapovijed i opis posljedice izostane li njezino izvršavanje, u CGrš nalazimo više skraćenih uputa povezanih anaforom te pretvorenih u zapovijedi, opomene i upozorenja. Iako su te naredbe inspirirane starozavjetnim knjigama, one ne predstavljaju prijevode nego slobodne parafraze najčešće nekoliko redaka pojedine mudrosne knjige. Npr. savjet: Ne hodi po gradu fraěe ili migae da ne budeš posmiěn mogao bi se protumačiti kao parafraza Izr 10,9-10: iže hoditb priproĉ'ta hoditb upvanê a iže krivits putb svoi hoditb êvlens budetb migaetb že okomb lastnê $i$ zbiraetb $m(u) z ̌ e m b ~ s ' k r b b$ a obličue ne obinue smêraet' $i, \mathrm{Vt5}$ 176a. ${ }^{28}$ Parafraze u završnom dijelu predstavljaju zapravo sažete savjete, paradigme za dobar život, čija je pouka intenzivirana unosom imperativnih forma (budi, nemoj) i priloga vazda/nigdar (vazda razmisli konac). Riječ je o onome što Lučin u Dobrim naucima, Marulićevoj pučkoj propovijedi u stihovima, naziva snažnom nagovornom impostacijom koja se očituje u čestom neposrednom obraćanju primateljima, koje prate imperativi, afektivni uzvici i dr. ${ }^{29} \mathrm{Na}$ određenoj bi se razini Zbirka doista mogla usporediti s navedenim Marulićevim djelom, ${ }^{30} \mathrm{u}$ kojem se nižu stihovane upute za dobar život: Ne bud lin ali gluh, ča t'vele, obsluži / Vazda sveti posluh s vesel'jem uzdarži (...) Poštuj starišine koliko s' uzmožan / I ostale ine, svim budi podložan (...) Ki se boga boje, tašćine sve tlače / Put svoju ne goje u grih se ne slače / Blažen človik komu podan je božji strah / U svem dilu svomu pomišlja da je prah / Pusti svoje volje, tarpi cića boga / Još dušu t’nevolje, da plaća je mnoga. ${ }^{31}$

\footnotetext{
${ }^{28}$ V. ČERMÁK, 2001, 160.

${ }^{29}$ B. LUČIN, 1999, 67.

${ }^{30}$ B. LUČIN, 1999, 66-67.

${ }^{31}$ M. MARULIĆ, 86-87.
} 


\section{Pitanje izvornosti Zbirke sentencija}

U Zbirci, pogotovo u verziji u CGrš, oslikavaju se glagoljaški postupci spajanja i mijenjanja već poznatih tekstova. Riječ je o onome što se zove fluidnost, odnosno mouvance, i što još jednom potvrđuje aktivnost unutar tzv. glagoljaške zajednice ${ }^{32}$ gdje pisari/kompilatori/prevoditelji dijele sličnu lektiru čije poznavanje pokazuju na razne načine: bilješkama na marginama, upućivanjem na drugu knjigu koja sadrži isti ili sličan tekst, koje zamjenjuje prevođenje/prepisivanje pojedinog teksta i $\mathrm{dr}^{33}$ Otvorenost forme ${ }^{34}$ vidi se u slobodnom preuzimanju citata, djelomice i/ili u cijelosti, njihovu kraćenju, izmjeni pojedinih riječi, grafičkom oblikovanju teksta, položaju koji tekst zauzima u rukopisu i dr. Pomnim čitanjem utvrđeno je kako postoji više formalnih i sadržajnih sličnosti između Zbirke i nekoliko glagoljskih tekstova. ${ }^{35}$

Prvo, adresiranje sinu tijekom iznošenja savjeta za dobar život, za što potvrdu nalazimo u posljednjem retku Zbirke u CPet (Ne budi sinu opiêvac'ni lûbodêinik') predstavlja stalno mjesto u gnomičnim tekstovima: ${ }^{36}$ od mudrosnih biblijskih knjiga, Disticha Catonis (Pišu se knige sinu Katovu ne tuliko sinu da vsakomu č(lovê) ku ki ga hoĉe poslušati i razumiti, CPet, 86r), Nauka sinu Vičerdovu (Dragi sinu govori ti Vičerd' koliko ti e biti mudru brumnu i počtenu, CGrš, 130v), Priči o premudrom Akiru (Sinu moi Anadane) i dr. Takvo adresiranje Čermák nalazi čak i u prijevodima pojedinih citata iz brevijarskih čitanja Mudrih izreka, za što potvrdu ne nalazi ni u Vulgati, ni u Septuaginti ni u latinskim brevijarima, ali zato nalazi u parimejnim izvorima: "U knjigama proroka piše: tako glagoletb gospodb

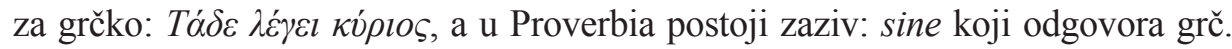
vié, što ni u biblijskom tekstu ni u latinskom brevijaru nije potvrđeno." ${ }^{37}$ Također, ne smije se isključiti mogućnost utjecaja didaktičnih tekstova, koji su se između ostaloga sastojali od navoda iz mudrosnih knjiga, ali i samih biblijskih čitanja koja sadržavaju slična adresiranja (npr. Knjiga Sirahova), na prijevode onih citata u kojima se ona izvorno ne pojavljuju.

${ }^{32}$ O tome vidi više u A. RADOŠEVIĆ, 2017; A. RADOŠEVIĆ - M.-A. DÜRRIGL, 2020.

${ }^{33}$ A. RADOŠEVIĆ, 2017.

${ }^{34}$ Vidi M.-A. DÜRRIGL, 2010.

${ }^{35} \mathrm{U}$ ovom radu pomnim čitanjem nastojali smo utvrditi glagoljašku lektiru kojom je kompilator/pisar Zbirke mogao biti nadahnut tijekom stvaranja/prepisivanja teksta. Uzimajući u obzir važnost pamćenja (ars memorativa) u srednjem vijeku cilj je bio usporedbom s hrvatskoglagoljskim brevijarima, tj. liturgijskim knjigama u kojima je sačuvan znatan dio čitanja iz mudrosnih knjiga, utvrditi je li kompilator/pisar u stvaranju teksta bio pod izravnim/neizravnim utjecajem i glagoljskih liturgijskih knjiga. Stoga smo zbirku usporedili s više srednjovjekovnih tekstova te s hrvatskoglagoljskim brevijarima.

${ }^{36}$ B. TAYLOR, 1992, 25.

${ }^{37}$ V. ČERMÁK, 2004, 151. Prema V. BADURINA STIPČEVIĆ, 2019, 157. 


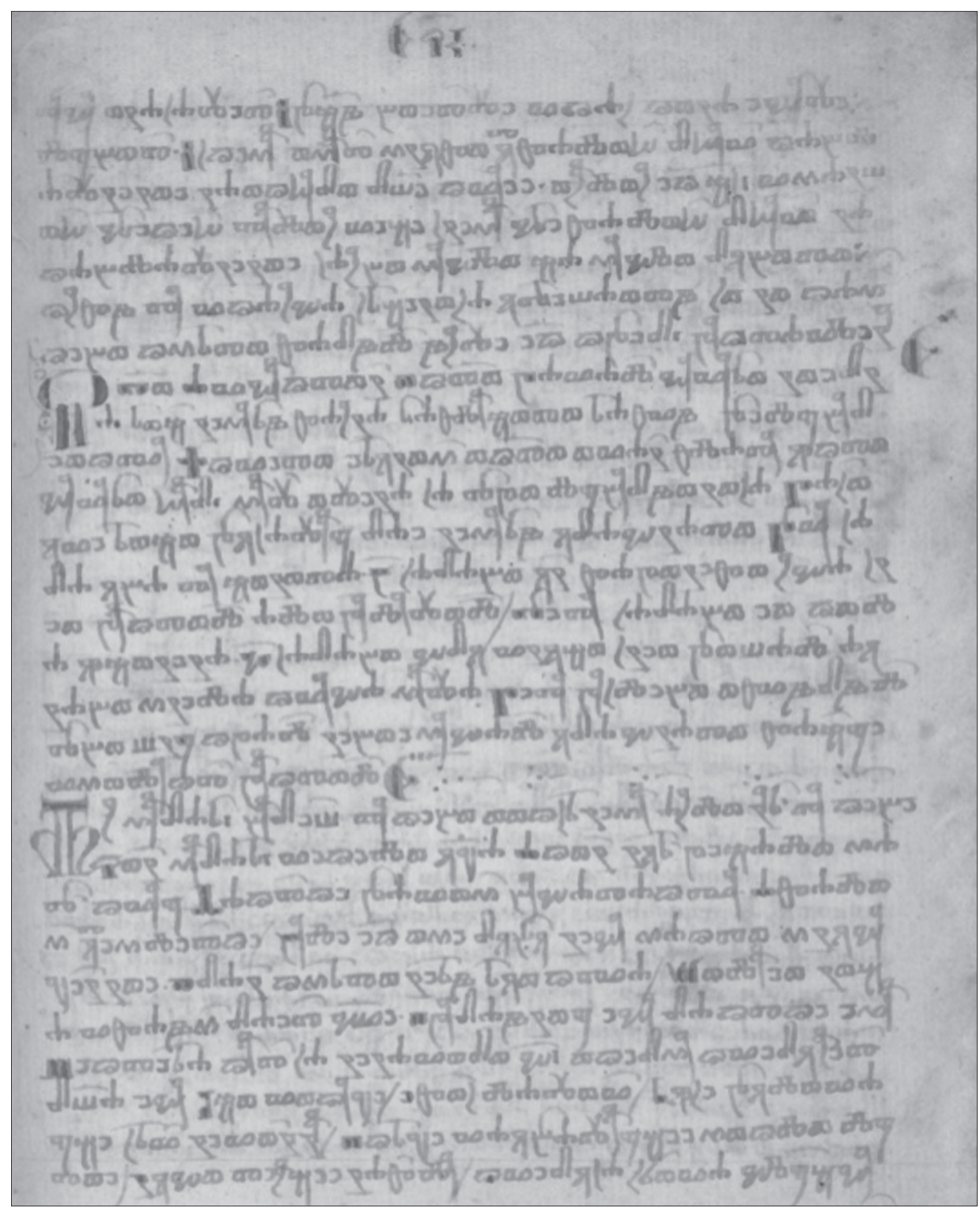

Sl. 1. Početak Zbirke sentencija u Petrisovu zborniku (izvor: NSK, sign. 4001, 238r.)

Drugo, u Zbirci i Priči o premudrom Akiru nalazimo iste kraće cjeline sastavljene od nekoliko izreka i njihovih parafraza u kojima se iznose savjeti: Začelo premudrosti strah'gospodan. V tom'budi skor slišati, a kasan'otgovoriti 
Trpeliv'v gnivi, CGrš 188v; Prvo načelo prêmudrosti est'strah'g(ospodb)nь. Po tom'budi skor slišati A kasan' govoriti u gnevê trpêliv', CPet 96v, čime počinje prvo Akirovo obraćanje Anadanu. ${ }^{38}$ Nakon prvoga navoda iz Sir 1,14 slijedi drugi koji pripada Sir 5,11, no u takvom parafraziranom obliku ne nalazimo ga ni u jednom od četiri glagoljska brevijara u kojima je navedeno čitanje nastalo

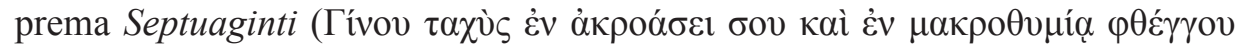

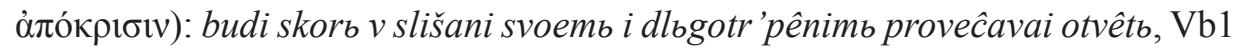
238c, Vb2, 248a, Vb3 294b, VO 375d. Na temelju toga pretpostavljamo kako su sintagme u oba zbornika nastale prema dosad neutvrđenom tekstu.

Treće, nekoliko grafičkih simbola u CPet koji označavaju početak nove tematske cjeline daju naslutiti kako je u tekstu prema kojem je nastala Zbirka postojalo više cjelina odvojenih istim ili sličnim simbolima, odnosno da je taj prvotni tekst bio ipak dulji te da je možda čak nastao prema nekoj vrsti florilegija.

Četvrto, pojedine tematske sličnosti s drugim tekstovima upućuju kako je kompilator/pisar pri sastavljanju zbirke mogao biti dijelom nadahnut tzv. glagoljaškom lektirom. Krajnja opomena o izbjegavanju prelûbodeistva (Ne budi sinu opiêvac'ni lûbodêinik' da ne obnićašs' zač 'ki obnića v poruganii budê, 239r) kojom završava Zbirka u CPet, a u kojoj se kvalificiraju dva tipa grešnika (preljubnik i pijanica), može biti dovedena u vezu s Prenjem Duše i Misli u kojoj duša upozorava misao da se kloni proklete superbije, navlasitio grjeha nečistoga pltenoga, to jest pretužno ljubodjejanije. I kaže da govori sveti Pavao da nijedan ljubodjejnik nema pričastija ni djela u cesarstvu božjem, ${ }^{39}$ ali i s kratkim tekstom o prelûbodeistvu koji u CPet izravno prethodi Zbirci: S(ve)ti Avgustin'i s(ve)ti Paval' govori niedna rič ne morê zakona razlučiti razvê prelûbodeistvo. A sveti Eronim'i s(ve)ti Ivan'Zlatousti govori hud muž ižena ka trpiu lûbodêinika. Paki ove riči prokažuû da e ne morê odagnati. Prvo kada oba to činita .b. $(=2)$ kada bi on za pinezi kog k nei pustil ali položil. Treto kada bi ei sila učinena .g. (=4) kada bi gdo v noĉi k nei prišal a ona bi mnela svoga muža. Peto pokle bi ozvêdêl tr bi š nû spal'ne bi e mogal odagnati zač û e v milost pustil, 238r.

Nadahnutost navedenim Prenjem u CPet očituje se i umetanjem digresije kojom se prekida nizanje uputa: A poiti e duši na pakal'tužno tre nevolno svoe grehi na sebi žalostno nesući, 238v. Spominjanje duše u CPet u objašnjenju savjeta (Ne dai povolstva misli tvoei da ne budê zla d(u)ši tvoei, 238v) također

${ }^{38}$ V. BADURINA STIPČEVIĆ, 2015, 388-389. Pretpostavlja se da je ovaj kratak isječak koji se "u istom obliku pojavljuje kao dio narativne proze (Priča o premudrom Akiru), dio refleksivnog teksta (Kapitul), ali i kao dio zbirke sentencija (Petrisov zbornik) vjerojatno potjecao iz nekog srednjovjekovnog florilegija. (A. RADOŠEVIĆ, 2017)

${ }^{39}$ Hrvatska srednjovjekovna proza, 2013, 268. 
je bliska Prenju u kojem misao savjetuje dušu: A ti mudra i plemenita jesi zač si od mudrosti učinjena. A dana jesi telu da š njim živeš i da ti telom vladaš a da ne daš telu povolstva. ${ }^{40} \mathrm{~A}$ na drugome mjestu stoji: Zato, prosim te moja duše, čuvaj se moja duše od zla promišljenja, jere ti znaš da vsaki grijeh prija ima promišljenje nego učinjenje. ${ }^{41}$ Osim toga, i redoslijed kojim se na kraju Zbirke navode zapovijedi (Ne pii vina mnogo da tê ne povrati v norost. Ne jii vele krat va dne da vpadêš v bêteg', 239r) podsjeća na Prenje u kojem stoji: braćo ne opijajte se vinom zač v njem je vsaki blud i vsaka nečistota. Gdje su velika pitja i jedenja, tamo su i velika ljubodjeanija. Ako se vzdržiš od toga i oholosti možeš priti u kraljevstvo. ${ }^{42}$ Druga uputa također bi mogla biti nadahnuta posljednjim dijelom sedme glave Knjige Sirahove o umjerenosti, a na temelju koje je oblikovana parafraza: noli avidus esse in omni epulatione et non te effundas super omnem escam in multis enim escis erit infirmitas et aplestia adpropinquabit usque ad cholera (Sir 37,32-33).

Dok u Prenju misao upućuje dušu kako da ponovo uđe u "dvari nebeske", u zbirci se motiv ulaska u kraljevstvo nebesko pojavljuje u sklopu krajnje opomene: Ne zatavarai dvari tvoih' pred' ubogim' da gospodin' B(og) tebi ne zatvori vrat raiskih', CGrš 189r; Ne zatvori dvari tvoih' pred ubogimi da ne zatvori $B(\text { og })_{b}$ $d$ vari svoih 'pred tobu, CPet 239r. Za razliku od duše koja se pokušava vratiti u $d v a r i$ nebeske, primatelju Zbirke iznosi se više savjeta i zapovijedi kako izbjeći mogućnost ostajanja izvan vrata i Božjega milosrđa.

Peto, različit položaj zbirke unutar dvaju rukopisa pokazatelj je mouvancea glagoljaških tekstova. Naime, kompilator Kapitula u želji da u CGrš od dvaju tekstova (Pseudo-Bernardova traktata i Zbirke) oblikuje sermon umjesto propovjednog egzempla za svoj je treći dio odabrao zbirku sentencija u kojoj se konkretiziraju i sintetiziraju tvrdnje o mudrom životu. Takav izbor ne bi nas trebao suviše iznenaditi s obzirom na to da propovjedni egzempl ${ }^{43}$ i izreke dijele dva prepoznatljiva obilježja (persuazivnost i didaktičnost). Umjesto unosa nekoliko egzempla kojima bi moglo biti obuhvaćeno svega nekoliko tema, kompilator ove propovijedi tvrdnju o mudrom životu obradio je posegnuvši za tekstom koji sadrži niz sentencija sastavljenih od sintetiziranih životnih iskustava. Naime, odabirom nekoliko egzempla ne bi se uspjele obuhvatiti sve životne situacije čije poznavanje omogućuje mudar život. S obzirom na to da je riječ o relativno kratkoj kompilaciji

${ }^{40}$ Hrvatska srednjovjekovna proza, 2013, 269.

${ }^{41}$ Hrvatska srednjovjekovna proza, 2013, 267.

${ }^{42}$ Hrvatska srednjovjekovna proza, 2013, 269.

43 Riječ je o kratkim narativnim tekstovima kojima se oprimjerivala određena pouka (sentencija) s ciljem da se i onima najskromnijega obrazovanja približe crkvena učenja. 
propovijedi, kako bi se koliko-toliko sačuvala njezina struktura i središnja tematika, dodani tekst kojim se oprimjeruju općenite tvrdnje nije smio premašiti duljinu osnovnoga teksta, pogotovo stoga što je usmeni karakter hrvatskoglagoljskih tekstova često uvjetovao odabir lako pamtljivih i kratkih književnih formi. Tako se poruka teksta nije zadržala na općenitim razmatranjima o veličini i važnosti mudrosti, nego se spustila na nižu razinu, a to je njezino oprimjerivanje. Mudrost kao opreku ludosti ${ }^{44}$ trebalo je stoga u određenoj mjeri prizemljiti iznošenjem konkretnih primjera. Stavljanje naglaska na djelomičnu konkretizaciju mudrosti, zapravo je pozivanje publike da svakodnevnim razmišljanjem o mudrom životu razviju sposobnost razlučivanja dobra i zla. Takav postupak u kojem se ogleda skrb oko mogućnosti recepcije potencijalnih primatelja djelomice je sličan onome u Marulićevim Dobrim naucima koji su pisani jednostavnim stilom prilagođenim širem slušateljstvu/čitateljstvu. Kako govori Lučin u svojoj studiji: "Pučka propovijed, naime, ne postiže svoj cilj teorijsko-argumentacijskim, nego pragmatičnim pristupom: u njoj se ne razmatraju vjerske dogme, nego se iznose praktične moralne pouke (...) Umjesto učenom argumentacijom, Dobri nauci služe se drugačijim nagovornim sredstvima." 45

Kada govorimo o Zbirci iz CGrš treba se osvrnuti i na poveznicu $\mathrm{s}$ Pseudo-Bernardovim traktatom. U kratkom odlomku inspiriranom Pavlovom poslanicom Galaćanima 5,17-21 (o opasnostima prepuštanja tjelesnim užitcima) ističu se vrline važne u monaškoj zajednici - patientia, izbjegavanje tjelesnoga, skladnost među braćom. Osim toga, odlomak podsjeća i na dijelove postila, komentara u kojima se tumače određene riječi (oznaka pojašnjivača to est): trplivim' biti vsagda to e(st) ne lûbiti suetnih' vika, CGrš 188r. Taj odlomak zapravo "predstavlja prijelaz s učenja o ljubavi na konkretiziranje grijeha koji će se, između ostalog, navoditi u mudrim izrekama." ${ }^{46}$ Poslanica Pavla apostola, novozavjetnoga nositelja mudrosti i prema nekima novoga Salomona u čijim riječima kršćanska učenja postaju mudrosna, a propovijedanje postaje najava riječi Božje (Ef 3,10), tako stupa u izravnu vezu s citatom o Sedam gnusoba iz Mudrih izreka (Šestera sut ka nenavidit gospodin i sedmero svedokuet duša ego: oči visokie, êzik lažliv, ruke prolivaûce krv nevinnu, i srce va obražû̂ce,

44 Konkretiziranje uputa $u$ dobar život temelji se na antitezi mudrost-ludost. U srednjovjekovnom poimanju svijeta mudrost je opreka ludosti te kao posljedica neopreznosti i pomanjkanja mudrosti ne predstavlja ništa drugo doli bezboštvo, nepriznavanje Božjeg zakona te se u konačnici pretvara u prijetnju koja čovjeka može udaljiti od spasenja.

${ }^{45}$ B. LUČIN, 1999, 67.

${ }^{46}$ A. RADOŠEVIĆ, 2017. 
misli lûtie, nogi tekuĉe na zlo, govoreĉih laž, svedoka kriva. I togo ki sie mê̂ bratiû nenavist', 188rv). Dodajmo kako je u CPet pojam grijeha/grešnosti bio više intenziviran: Ako pravadni edva sp(a)set se, a grešnik' kadê êvit'se, 238v; A poiti e d(u)ši na pakal' tužno tre nevolno svoe grehi na sebi žalostno nesući, 238v. Završetak zbirke u CGrš, koji se razlikuje od onoga u CPet, pokazuje kako kompilatorova posljednja tvrdnja sadrži zrnce poopćavanja u odnosu na prethodno spomenute sentencije. Kompilator je takvim završetkom nastojao poručiti kako on uključuje i ostale nespomenute upute, odnosno kako nije moguće navesti sve primjere mudroga života.

U Zbirci, nešto više u inačici iz CGrš, nalazimo parafraziranja i izostavljanja apelativnih dijelova biblijskih citata (izbacivanje izraza kao što su a ja vam kažem, nego, velim vama koji slušate) s namjerom učinkovitijega isticanja njihove ekspresivnosti i gnomičnosti. $\mathrm{S}$ jedne se strane izbjegava njihov kontekst, a s druge ih se strane nastoji povezati na stilsko-sintaktičkoj razini. Npr. iz Knjige Sirahove kompilator u CGrš samo uzima sintagmu vazda razmisli konac' (Sir 7,36) dok u Vulgati ${ }^{47}$ navod glasi: in omnibus operibus tuis memorare novissima tua et in aeternum non peccabis. Verzija toga istoga citata u CPet (A kada ča hoĉ učiniti učini e mudro i vazda misli niki konac hoĉe tvoe činenie priti, 238v) slična je verziji iz Cvijeta kreposti iz Vinodolskoga zbornika: K'da nêku rêć 'učiniti hố' učini û mudro da v'zda mis'li prêe ki kon(a)c' hoce prieti, 53d. ${ }^{48} \mathrm{U}$ tome se glagoljskom zborniku ova izreka pojavljuje u kapitulu Ot mudrosti i to kao dio egzempla unesena iz Ištorie rim 'ske u kojemu car (cêsar) moli filozofa da ga poduči mudrosti: prošu te nauči me nêke mudrosti.

Dio Zbirke građen je na sintaktičkim paralelizmima, tj. uzastopnom ponavljanju rečeničnih konstrukcija: Ne imii družbi sa ženu lukkavu da ne izgorišs' ognem' ee, Ne imii družbi sa starišinu mesta na poslišai riči nega, Ne pit vina mnogo da te ne povrati v norost', CGrš, 189r. Završetak Zbirke, ujedno i kompilacije, u CGrš obilježen je paralelizmom na sintaktičkoj i na tematskoj razini. Nakon sedam sintaktičkih paralelizama u završnoj se rečenici ostvaruje značenjski paralelizam: I kako budeš miril tako se i tebi mirilo bude, CGrš 189r. Oblik ove izreke u CPet (Ku meru budeл' meriti tako se tebi budê meriti) vrlo je sličan izreci iz Cvijeta kreposti: meru ku budešb mirilb miriti se hoĉe t(e)bê, Ljubljanski zbornik, $7 \mathrm{v} .{ }^{49}$

${ }^{47}$ U ovome radu citati iz Vulgate i Septuaginte citiraju se prema elektroničnom izvoru: https://www.academic-bible.com/en/online-bibles/about-the-online-bibles. (2021-8-31)

${ }^{48}$ Prema A. ZARADIJA KIŠ - M. ŠIMIĆ, 2020, 174.

${ }^{49}$ Prema A. ZARADIJA KIŠ - M. ŠIMIĆ, 2020, 170. 


\section{Usporedba Zbirke sentencija s hrvatskoglagoljskim brevijarima}

$\mathrm{S}$ obzirom na to da se Zbirka u velikoj mjeri sastoji od prijevoda i parafraza biblijskih citata, sljedeći je korak bio usporediti citate s čitanjima iz hrvatskoglagoljskih liturgijskih knjiga. ${ }^{50}$ Naime, upravo je u liturgijskim knjigama sačuvana polovica nekadašnje hrvatskoglagoljske Biblije na hrvatskocrkvenoslavenskom jeziku. ${ }^{51}$ Utvrđeno je kako se dio citata gotovo podudara s onima iz hrvatskoglagoljskih brevijara u kojima se, iako ne $\mathrm{u}$ istom obujmu, čuvaju čitanja iz pojedinih glava mudrosnih knjiga. ${ }^{52}$ Hrvatskoglagoljski brevijari dijele se na dvije skupine: u prvu ulaze oni $\mathrm{s}$ prijevodima bliskim parimejnim tekstovima i grčkim predlošcima, tj. oni iz sjeverne skupine ( $\left.\mathrm{VO}, \mathrm{Vb}_{1}, \mathrm{Vb}_{2}, \mathrm{Vb}_{3}, \mathrm{Pad}, \mathrm{MR}, \mathrm{Mavr}\right){ }_{5^{53}}$ a u drugu oni u kojima su prijevodi redigirani prema latinskim predlošcima $\left(\mathrm{Ber}_{2}, \mathrm{Dab}\right.$, Mosk, $\left.\mathrm{N}_{1}, \mathrm{Vt}_{5}\right) \cdot{ }^{54}$ Najviše lekcija iz Mudrih izreka sadržavaju Dab, Mosk, $\mathrm{N}_{1}, \mathrm{~N}_{2}, \mathrm{VO}$ i $\mathrm{Vt}_{5},{ }^{55} \mathrm{u}$ kojima izbor čitanja slijedi lekcije iz staroslavenskih parimejnika.

${ }^{50} \mathrm{~S}$ obzirom na to da se većina citata iz Zbirke nalazi u brevijarima, a ne u misalima, to se ovdje nećemo posvetiti misalskim čitanjima mudrosnih knjiga koje imaju sličnosti s parimejnim prijevodom. (J. REINHART, 1986, 80-81)

${ }^{51} \mathrm{O}$ izazovnim pitanjima vezanim za postojanje hrvatskoglagoljske Biblije vidi više u BADURINA STIPČEVIĆ, 2010, 384-386.

${ }^{52}$ O tome su pisali V. ČERMÁK, 1999, 2001, 2004, 2007; A. ZARADIJA KIŠ, 1997; I. MILIČIĆ, 1999; I. BAKMAZ, 2004; I. HRISTOVA SHOMOVA, 2021; V. BADURINA STIPČEVIĆ, 1994, 1996, 2019. Bakmaz kaže da gotov potpun tekst Propovjednika $(1,1-12,14)$ nalazimo u Dab, $\mathrm{N}_{2}$, Mosk, Vat ${ }_{5}$, a Prop 1,1-11,5 u Vb $\mathrm{Vb}_{3}$, VO. U istoj skupini brevijara, uključijući i Pad, nalazimo i jednak opseg teksta iz Knjige Mudrosti (1, 1-6, 25) i Knjige Sirahove $(1,1-6,17)$. Deuterokanonske knjige, pa tako i Knjiga Mudrosti i Propovjednik prevedene su po uzoru na latinsku Bibliju, Vetus Latina i Jeronimovu Vulgatu. S druge strane, kod Mudrih izreka postoje dvije verzije: starija je "bliska parimejnim tekstovima grčkoga podrijetla, a mlađa verzija prevedena je s latinskoga predloška ili prijevodnim preinakama prilagođena Vulgati". (V. BADURINA STIPČEVIĆ, 2019, 158-159)

${ }_{53}^{5}$ V. ČERMÁK, 2004, 151. O Nahtigalovim istraživanjima Biblije, uključujući i Mudre izreke, vidi BADURINA STIPČEVIĆ, 2019.

${ }^{54}$ V. ČERMÁK, 2001; J. TANDARIĆ, 1993, 33; prema V. BADURINA STIPČEVIĆ, 2019, 156-157. Drugu skupinu brevijara (B) čine spomenici koji u prvom dijelu Mudrih izreka slijede latinski model, u drugom dijelu prelaze na grčki model ne narušavajući tekstualnu podjelu. Ova skupina pripada većem broju spomenika različite dužine čitanja, od kojih su zanimljivi rukopisi s dugim lekcijama. Specifična podjela pojavljuje se u rukopisu $\mathrm{N}_{2}$, u kojem postoji prijelaz s jednog neslavenskoga modela na drugi na više mjesta nego u ostalim spomenicima skupine B. U $\mathrm{N}_{2}$ čitanja iz Izr 1,1-3,35 nastala su prema Vulgati, a Izr 4,1-7,8 prema Septuaginti. (V. ČERMÁK, 2011, 88)

${ }^{55}$ Popis se nalazi u V. ČERMÁK, 2001, 9-13. 
Naime, upravo citati iz Mudrih izreka ${ }^{56}$ čine znatan dio Zbirke, uz ipak manji udio citata iz Knjige Sirahove i Propovjednika.

Zbirka tako sadržava citate koji se nalaze u većini hrvatskoglagoljskih brevijara, ali i one zastupljene samo u onima s duljim lekcijama (Dab, Mosk, $\mathrm{N}_{1}, \mathrm{~N}_{2}, \mathrm{Vt}_{5}, \mathrm{VO}$ ). Pri tome je nužno istaknuti kako su upravo na tim mjestima, točnije onima u kojima izbor brevijarskih čitanja slijedi izbor u parimejnicima, citati iz Zbirke i navedenih nekoliko brevijara vrlo slični. Navest ćemo primjer iz Izr 19,17 koji se u gotovo istom obliku pojavljuje u CPet i CGrš te u brevijarima Dab, $\mathrm{N}_{1}, \mathrm{~N}_{2}$, Mosk i $\mathrm{Vt}_{5} .{ }^{57} \mathrm{U}$ oba zbornika u citatu je sačuvano više hrvatskocrkvenoslavenskih oblika: prezentski nastavak za 3. lice množine (-t/-t') i potvrda uporabe osobne zamjenice ego u izricanju posvojnosti.

Milûe niĉa v zaêm daet gospodeve i podaniû ego vzdast se emu, CGrš $188 \mathrm{r}$ Miluet niĉa v zaêm' daet' g(ospode)ve i podaêniû ego dast se emu, CPet 238r Miluei niĉa v' zaêmb daetb g(ospode)vê podaniû že ego dastı emu, Dab $78 b$ Milue niĉa $v$ zaêmb daets $g$ (ospode)vê podaniû že ego dastb emu, $\mathrm{N}_{2} 195 \mathrm{a}$ Miluei niĉa v' zaêmb daet' $\mathrm{g}$ (ospode)vê podaêniû že ego dastb emu, $\mathrm{Vt}_{5}^{58} 176 \mathrm{c}$, Mosk 185d

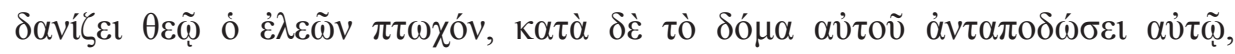
Septuaginta

Drugi navod iz Izr 19,22, sačuvan je u istoj skupini brevijara, no u ovome slučaju citat iz Zbirke podudaran je najviše $s$ citatom iz $\mathrm{Vt}_{5}$, izuzev izbacivanja zamjenice niĉb, dok se od ostalih razlikuje i u zamjenjivanju crkvenoslavenskoga komparativa luč 'ši (N2), luči (Mosk, $\mathrm{N}_{1}$, Dab) starohrvatskim boli (CPet, CGrš, $\mathrm{Vt}_{5}$ ). Riječ je o navodu nastalu prema Septuaginti.

Boli e ubog' veran', nere bogat' lažliv', CGrš 188v

Boli e ubog veran' nere bogat laživ, CPet 238v

Luči ubog niĉs vêranı neže bogat lažb, Dab $78 \mathrm{c}$

Luči ubo niĉs vêranь neže bogatı lažb, Mosk 185d

Luč'ši e niĉb vêr(a)nb neže bogat lažanb, $\mathrm{N}_{2} 196 \mathrm{~b}$

Boli ubo niĉ v(ê)r(b)nь neže bog(a)tb lažb, $\mathrm{Vt}_{5}^{59} 176 \mathrm{c}$

${ }^{56} \mathrm{U}$ prvih devet glava Salomonovih mudrih izreka dominiraju moralne poduke upućene sinu, a od desete do dvadeset i druge glave dominiraju etičke maksime pisane u 3. licu koje opisuju dobar život. (A. WOLTERS, 2020, 125-126, 177)

${ }^{57}$ V. ČERMÁK, 2001, 25. Govori kako su čitanja Pr 17,25-18,4 i 19,16-25 u Dab, Mosk, $\mathrm{N}_{1}$, $\mathrm{N}_{2} \mathrm{i} \mathrm{Vt}_{5}$ paralelna čitanjima iz parimejnika Izr 17,17-18,5 i 19,16-25.

${ }^{58}$ V. ČERMÁK, 2001, 169.

${ }^{59}$ V. ČERMÁK, 2001, 169. 
Et melior pauper quam vir mendax, Vulgata

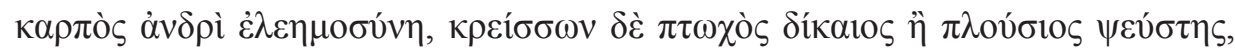
Septuaginta

U sljedećem primjeru iz Izr 9,12 prva polovica citata iz CPet i CGrš bliska je Septuaginti (sebi i iskrnemu), no u drugome dijelu parafraza citata bliža je Vulgati. Ovo nije jedini primjer da se drugi dio mijenja s ciljem stvaranja retoričke figure, u ovom slučaju antiteze: umjesto premudar i zao imamo mudar i nor/manen.

Ako mudar' budeši to sebi iskarnim, ako li manen' to sam sebi, CGrš $188 \mathrm{r}$ Ako mudar budeš' to sebi i iskrnemu, ako li nor' to sebe, CPet $238 \mathrm{r}$ Aĉe mudarı budeši to s(e)bê i isk'rnemu aĉe li norı budeši toli sebê, Dab 77c Aĉe li mudarb b(u)deši toli sebi i is'kr'nima ako li norı b(u)deši to sebi, Mosk $184 d$

Aĉe mudarı budeši to s(e)bê i iskrnemu aĉe li norı budeši tolê sebê, $\mathrm{N}_{2} 194 \mathrm{~b}$ S(i)ne moi, aĉe prêmudr' budeši sebê mudr' budeši i isrkbnnim' tvoimb, ace li zblb budeši edin počr'peši zblaê, VO 357d

Aĉe mudarb bud(e)ši toli sebê i iskr(b)nimb aĉe li ne b(u)d(e)ši to sebê, $\mathrm{Vt}_{5}, 175 \mathrm{~d}$

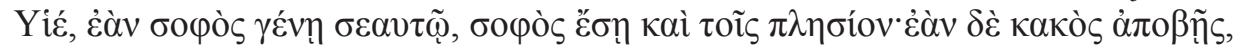

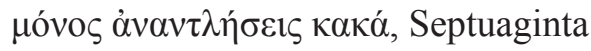

Si sapiens fueris tibimet ipsi eris si inlusor solus portabis malum, Vulgata

Citat iz Izr 12,4 vrlo je sličan navodima iz onih brevijara (Dab, Mosk, $\mathrm{N}_{1}, \mathrm{~N}_{2}, \mathrm{Vt}_{5}$ ) u kojima je tekst nastao prema parimejnicima i Septuaginti donekle izmijenjen. Naime, za razliku od VO te dvaju parimejnika (Zaharijev i F. I. 461) uz subjekt žena ne dolazi atribut vstanbliva nego dobra. Drugi dio izreke iz CPet (kako črv'drevo gubit'muža) i ostalih brevijara podudaran je verziji iz Septuaginte ( epistoli Jovinijanu (28. Vita mulierum): Sicut in ligno vermis, ita perdit virum suum uxor malefica. U Zbirci su sačuvani hrvatskocrkvenoslavenski prezentski (pogiblaet', gubit') i pridjevski nastavci (svoego), no ipak je izostavljena čestica $\check{z ̌ e ~ k o j a ~ s e ~ p o j a v l j u j e ~ u ~ s v i m ~ b r e v i j a r s k i m ~ l e k c i j a m a . ~}$

Žena dobra vinac' muža svoego est a žena huda pogiblaet' hišu muža svoego, CGrš $188 \mathrm{v}$

Žena dobra venac' mužu, a žena zla kako črv' drevo gubit' muža, CPet 238v

Žena dob'ra venacs mužu zala že êk(o) č'rvb drevo gubits muža, Dab 78b 
Žena dobra v(ê)n(a)сь m(u)žu a zla že a ki čr'vb d'rêvo gubitb m(u)ža, Mosk $185 \mathrm{~d}$

Žena dobra vênacs m(u)žu zla že êk(o) čr'vb drêvo gubits m(u)ža, $\mathrm{N}_{2} 195 \mathrm{~b}$

Žena vstanbliva vênьcь mužju svoemu êkože bo črbvb drêvo tako žena z'lodêiva gubit muža,${ }^{60} \mathrm{VO} 359 \mathrm{~b}$

Žena v(ê)n(a)cь m(u)žu zla že kako čr'vb drêvo gubits m(u)ža, $\mathrm{Vt}_{5}{ }_{5}^{61}, 176 \mathrm{bc}$

Mulier diligens corona viro suo et putredo in ossibus eius quae confusione res dignas gerit, Vulgata

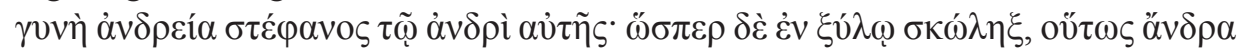

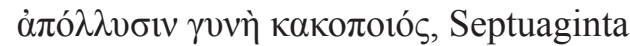

Citati iz Izr 6,16-19 gotovo je isti u CGrš, CPet, $\mathrm{Vt}_{5}$ i Ber ${ }_{2}$, a nastao je prema Vulgati. ${ }^{62}$ Epitet b'rzie uz riječ noge nalazi se samo u Ber ${ }_{2}$, Mosk, $\mathrm{N}_{1} \mathrm{i}$ Dab. Citati se razlikuju u prijevodu posljednje rečenice lat. seminat inter fratres

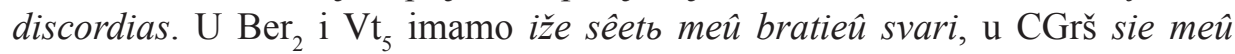
bratiû nenavist', a u CPet ki čini mêû brat'û svadu. U oba zbornika na mjestu hrvatskocrkvenoslavenske zamjenice êže dolazi zamjenica $k a$, a na mjesto iže zamjenica ki. U CGrš zabilježena su dva hrvatskocrkvenoslavenska prezentska oblika (svedokuet, nenavidit), a u CPet po jedan prezentski (svedokuet) i participski $(g l(a g o l) \hat{u} \hat{c}(a) g o)$.

Šestera sut ka nenavidit gospodin i sedmero svedokuet duša ego: oči visokie, êzik lažliv, ruke prolivaûce krv nevinnu, i srce vaobražuûce, misli lûtie, nogi tekuĉe na zlo, govoreĉih laž, svedoka kriva . I togo ki sie meû bratiû nenavist', CGrš 188 rv

Šestera sut ka nenavidi $g($ ospod)b i sedmo svedokuet d(u)ša ego: oči visoce, ezik laživ', ruke prolivaûce krv nevin'nu i srce vaobražuûce misli lûtie, nogi tekuĉee na zlo, svedoka kriva, gl(agol)ûĉ(a)go lažu i togo ki čini mêû brat'û svadu, CPet $238 \mathrm{rv}$

Šes'tera sut' êže nenaviditb g(ospod)b i sed'mo s'vedokuetb d(u)ša ego . Oči visokie i êzikb laživi ruke prolivaûcee k'rvb nepovin'nuû sr(bd)ce v'obražaûcee misli lûtie . nogi b'rzie tekuceee na zlo s'vedoka k'riva i togo iže sêetb meû b'ratiû s'vari, Dab 76c, Mosk 183d-184a, Ber 2 233a

${ }^{60}$ Prijevod u VO nastao je prema grčkom predlošku. (V. ČERMÁK, 2001, 132)

${ }^{61}$ V. ČERMÁK, 2001, 164.

${ }_{22}$ Čermák kaže da je prvi dio Izr 1,1-6,35 nastao prema grčkomu u Vt $t_{5}$, Mosk, $\mathrm{N}_{1}$, Dab. U ovome citatu iz Izr 4,1-7,8 $\mathrm{N}_{2}$ slijedi grčku Septuagintu, kao i VO, te se zato i razlikuje od onoga iz Zbirke. (V. ČERMÁK, 2001, 40) Sličan prijevod nalazimo i u Zaharijevu parimejniku (f. 94v-96r) i F. I. 461. (V. ČERMÁK, 2001, 172) 


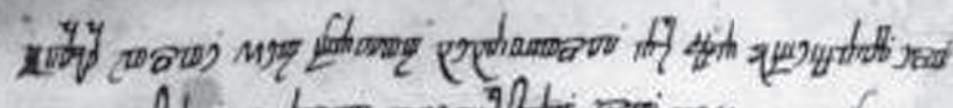

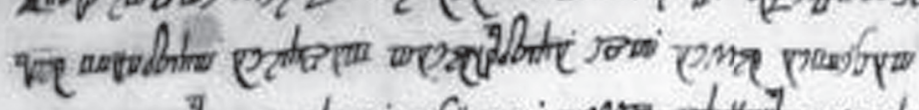
uy

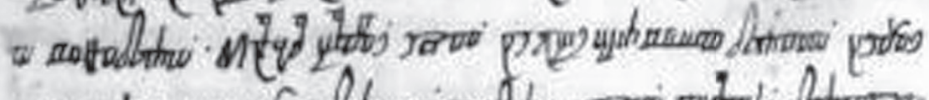

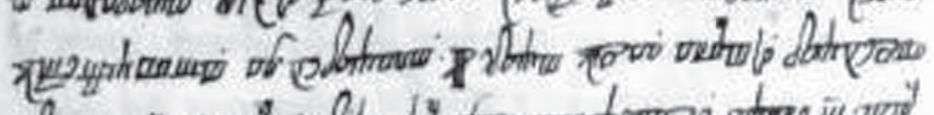

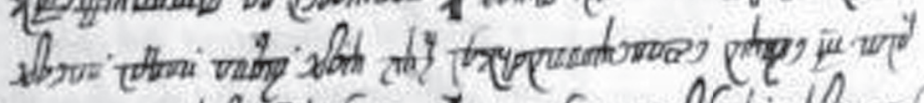

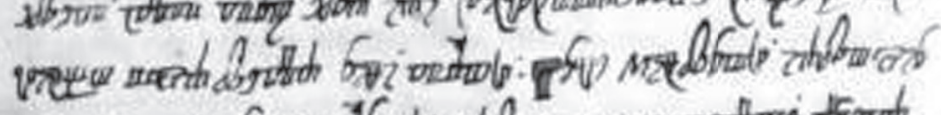

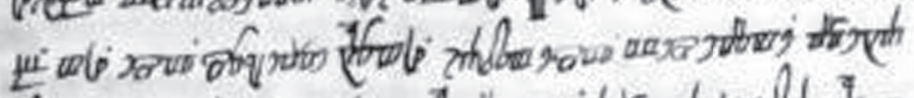

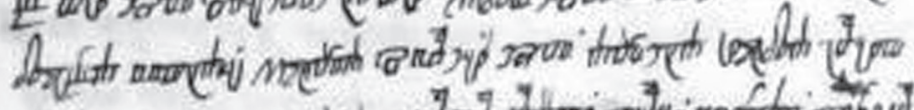

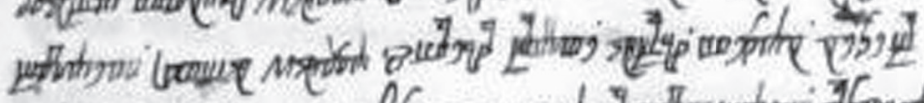

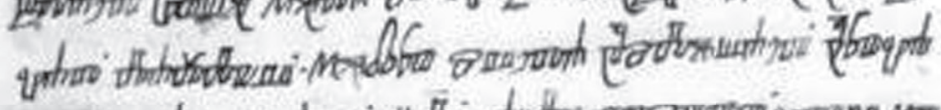

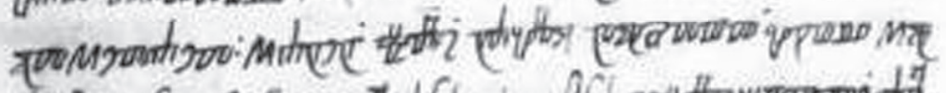

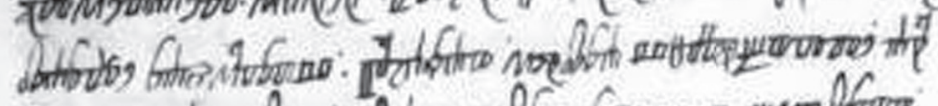

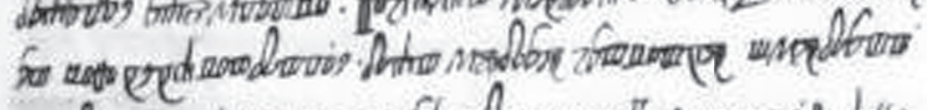

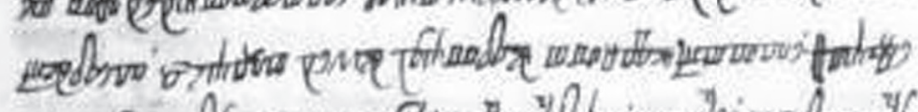

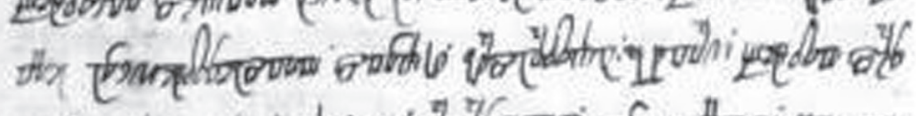

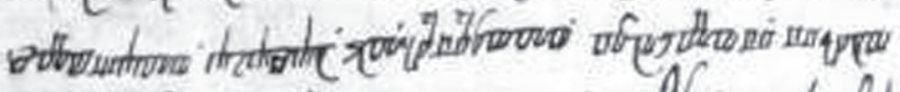

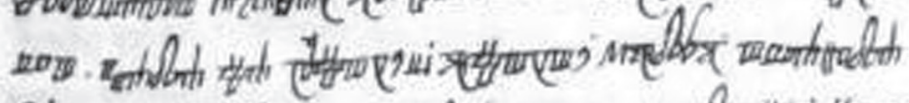

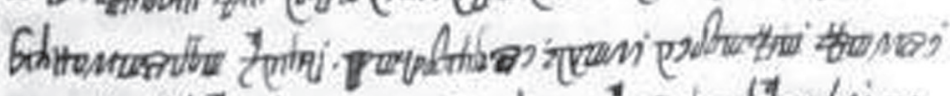
THy

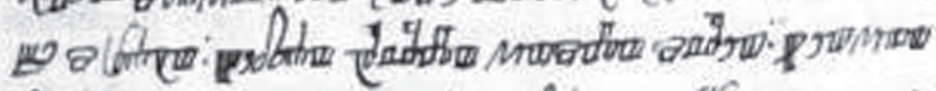

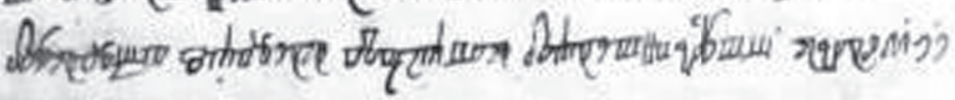

Sl. 2. Zbirka sentencija u Grškovićevu zborniku (izvor: arhiv HAZU, sign. VII 32, 188v.) 
Šestera sut' êže nenaviditı g(ospod)b i sedmo sv(ê)d(o)kuetb d(u)ša ego . Oči visokie ezikb laživb ruke prelaĉee krv nevin'nu sr(bd)ce v'obražaûcee misli lûtie . nogi tekuceee na zlo g(lago)lûciihь l(a)žu sv(ê)d(o)ka kr(i)va i togo iže sêets mei bratiû stvari, $\mathrm{Vt}_{5}{ }^{63} 175 \mathrm{a}$

Sex sunt quae odit Dominus et septimum detestatur anima eius oculos sublimes linguam mendacem manus effundentes innoxium sanguinem cor machinans cogitationes pessimas pedes veloces ad currendum in malum proferentem mendacia testem fallacem et eum qui seminat inter fratres discordias, Vulgata

Oblik citata Izr 12,15-16 u kojem je promijenjen redoslijed riječi povezuju Zbirku s brevijarima $\mathrm{N}_{2}$, Dab i $\mathrm{Vt}_{5}$. $\mathrm{U}$ istom se citatu pridjev nori dvaput pojavljuje jedino u CPet i N2, dok CGrš te $\mathrm{Vt}_{5}$, Mosk, $\mathrm{N}_{1}$ i Dab imaju po jednom: nori i manen te bezuman i nori. Zanimljivo je da svi brevijari, kao i CGrš i CPet, u prvom dijelu imaju dodatak nori ga otmetaet / bezumbnь že otimetb, kojeg nema ni u Septuaginti ni Vulgati ni parimejniku. Osim toga, citat u Zbirci i drugoj mlađoj skupini brevijara oblikovan je oko dvaju oprečnih odnosa mudrog i norog, prvo prema savjetu, a drugo prema gnjevu. Takva podudarnost mogla bi upućivati na zaključak da je kompilator zbirke dijelom zagledavao u neki od brevijara mlađe skupine.

Mudri sveta poslušaet, nori ga otmetaet'. Manen čl(ovê)k' naglo pustit' gniv, mudar že rasmotriv, CGrš $188 \mathrm{v}$

Mudar sveta poslušaet nori ga otmetaet. Nori že vnagle ispustit' gnev', mudar že smotrit', CPet 238v

Mudar s'vita poslušaetb bezumni že otmeĉets Nori v'naglê g'nevb isp(o)vêsts mudri že smotrit', Dab 78c

Mudarb svêta poslušaetb nori že otmeĉetb. Nori vnaglê g'nêvb isp(o)vêstb mudri že si smotritb, $\mathrm{N}_{2} 195 \mathrm{~b}$

Mudar sv(ê)ta poslušaet' bezumna že otmetaet' Nori vnaglê gnêvb ispustit' mudar že smotrit', $\mathrm{Vt}_{5}{ }^{64} 176 \mathrm{c}$

Poslušaetь svêta dobra mudr' bezumьnь že otimets. Bezumьn' v prıvi d(ь)nь ispovêdaet' gnêvb svoi . taits že svoe dosaždenie mudr', $\mathrm{VO}^{65} 359 \mathrm{~b}$

Poslušaet že savjeta premudrih bezumen v prvin $\mathrm{d}(\mathrm{a}) \mathrm{n}$ ispovedaet gnjev svoi tait že svoe dosaždenie mudrih, F. I. $461^{66}$

${ }^{63}$ V. ČERMÁK, 2001, 153.
${ }^{64}$ V. ČERMÁK, 2001, 165.
${ }^{65}$ V. ČERMÁK, 2001, 132.
${ }^{66}$ V. ČERMÁK, 2001, 195. 
Autem sapiens est audit consilia. Fatuus statim indicat iram suam qui autem dissimulat iniuriam callidus est, Vulgata

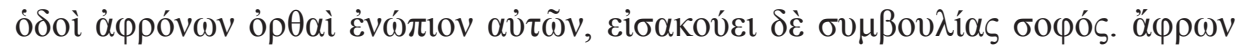

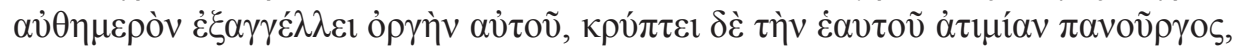
Septuaginta

U oba zbornika skraćen je citat iz Izr 9,8-9. Za razliku od VO, Dab, Mosk i $\mathrm{Vt}_{5}$ koji počinju zapovjednim tonom (ne ukarai, ne obličai), početak citata u N $\mathrm{N}_{2}$, CGrš i CPet pisan je onim savjetodavnim (pokarai). Ipak, jedino su u CGrš oba savjeta usredotočena na ophođenje prema mudromu kojemu se potom suprotstavlja ono prema noromu. U kasnijoj kompilaciji kao da se i na rečeničnoj razini nastoji podertati mudrost kao uzor ispravnoga života.

Pokarai mudra, vzlubit te, a nori vznenavidit te. Dai mudru krivinu i mudri budet, skaži nemu pravdu i vzlubit te, CGrš $188 \mathrm{v}$

Pokarai nora da te vznenavidit' a pokarai mudra i vzlûbit' te. Dai mudru krivinû i mudrêi budêt' i skaži emu prava i vzlûbit tê, CPet 238v

Ne ukarai norago da ne vznenavidit' te. Aĉe li mudra ob'ličaeši v'zlûbi te. Dai mudru vinu i mudrei budêtb i skaži pravê mudru i v'zlûbit' û, Dab 77c

Ne ukarai norago da ne v'znenavidit acee li mud'ra ob'ličišs vzlûbit' te. Dai mudru krivinu i premudrei b(u)detb i s'kaži praviša mudra i vzlûbit'ê Mosk 184d

Pokarai noriga da ne v'znenavidit' te aĉe li mudra obličaeši vzlûbit' te. Dai mudru vinu i mudrêi budetb i skaži pravaê mudru i vzlûbitb ê, $\mathrm{N}_{2} 194 \mathrm{~b}$

Ne obličai bezumnago da ne vznenavidits te obličai mudrago i vzlûbits te. Dažd' prêmudru vinu i premudrêi budet' skaži pravbdnu pravbdna i priložit' priemati, VO 357d

Ne ukarai norago da ne vzne(na)vidit-e aĉe li mudra obličaeši vzlûbi-t-e Dai mudru vinu i mudrêi budetı i skaži pravaê mudru i vzlûbit-e, $\mathrm{Vt}_{5}{ }^{67} 175 \mathrm{~d}$

Noli arguere derisorem ne oderit te argue sapientem et diliget te. da sapienti et addetur ei sapientia doce iustum et festinabit accipere, Vulgata

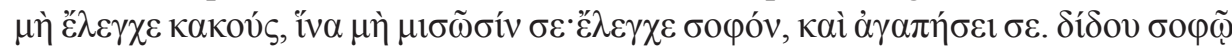

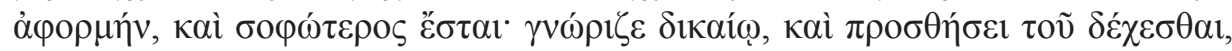
Septuaginta

Citat iz 1Pt 4,18 u CPet, izuzev zamjene hrvatskocrkvenoslavenskog veznika ace veznikom ako, i odabira poimeničnog pridjeva na mjestu subjekta (pravadni prema $\operatorname{pr}(a) v(a) d n(i) k b$ ) podudara se $\mathrm{s}$ citatom iz $\mathrm{Vt}_{5}$.

${ }^{67}$ V. ČERMÁK, 2001, 158. 
Ako pravadni edva sp(a)set se, a grešnik' kadê êvit' se, CPet 238v Aĉe bo prav(a)dnikb ed'va sp(a)s(e)t' se a grêšnikb g' dê êvit se, Dab 78b Acee bo pr(a)v(a)dnikb edva sp(a)s(e)t' se a grêšniks kadê êvit se, $\mathrm{N}_{2}$ 195a Aĉe prav(a)dnik' edva sp(a)set se nečistivi že i grêšnik kdê êvit se, $\mathrm{VO}^{68} 359 \mathrm{~b}$ Ace $\operatorname{pr}(\mathrm{a}) \mathrm{v}(\mathrm{a}) \mathrm{dn}(\mathrm{i}) \mathrm{kb}$ ed'va sp(a)set se a grêš'nik kadê êvit se, $\mathrm{Vt}_{5}{ }^{69} 176 \mathrm{~b}$ Et si iustus vix salvatur impius et peccator ubi parebit, Vulgata

U sljedećem primjeru iz Prop 7,1 zamjećujemo kako se u mlađoj verziji Zbirke u CGrš i svim glagoljskim brevijarima pojavljuje epitet prekrasnie, za razliku od epiteta mnogocenn'ie u starijoj verziji iz CPet. U oba se zbornika izbjegava ponavljanje imenice dan u drugom dijelu izreke (dan' semrti nere roistvo prema danb sem 'rti danb roždast'va) te se ona pojavljuje samo uz riječ semrt/smrt. Hrvatskocrkvenoslavenki neže zamijenjen je s nego i nere/nerê.

Bole e(stb) ime dobro, nego masti prekrasnie i dan' semrti nere roistvo, CGrš $188 \mathrm{r}$ Bole es(tb) ime dobro, nego masti mnogocen'nie i dan' smrti nerê roistva, CPet 238r Bole e(stb) ime dob'ro neže mas'ti prek'ras'nie i danb sem'rti danb roždast'va, Dab, 81c

Bole es(tb) ime dobro neže mas'ti prek'rasnie i d(a)nb roistva Mosk 189a

Bole e(stb) ime dobro neže masti prekrasnie i d(a)nb semrti neže d(a)nb roistva, $\mathrm{N}_{2} 198 \mathrm{~b}$

Bole est' ime dobro neže masti prêkrasnie i d(a)nb sem'rtni d(a)nь rožd'stva, VO $365 \mathrm{~b}$,

Vt5 179b

Melius est nomen bonum quam unguenta pretiosa et dies mortis die nativitatis, Vulgata

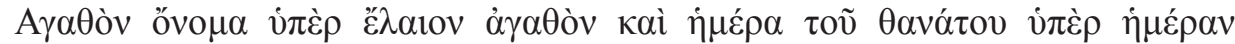

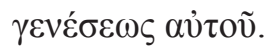

Ostatci pojedinih hrvatskocrkvenoslavenskih leksema povremeno se pojavljuju u CPet i CGršs, npr. čestica že u drugom dijelu citata iz Prop 7,4. Ipak, u prvome dijelu prilog ideže zamijenjen je riječima kadê i kadi. Osim toga, upravo se navedenim dvama citata iz Propovjednika o tome kako je bolji smrtni dan nego dan rođenja i bolja žalost nego radost uokviruje kraća cjelina sastavljena od navođenja postupaka mrskih Gospodinu.

\footnotetext{
${ }^{68}$ Sličan prijevod nalazimo u Zaharijevu parimejniku (f. 94v-96r) i u F. I. 461. (V. ČERMÁK, 2001, 172, 193)

${ }^{69}$ V. ČERMÁK, 2001, 163.
} 
Srce mudrih' kadi skrb' ih' est', srce že norih' kadi est veselie, CGrš 188v Srce mudrih' kadê skrb' es(t), srce že norih' kade es(t) veselie, CPet 238v Sr'ce mudr'ra ideže s'krb' estb s'rce že norihb ideže veselie, Mosk 189a Srce mudra ideže skrbs srce norihь ideže vesele e(stb), $\mathrm{N}_{2} 198 \mathrm{~b}$ Cor sapientium ubi tristitia est et cor stultorum ubi laetitia, Vulgata

Primjer iz Prop 5,3-5 u kojem se iznosi vjerska poduka pokazuje kako je na ovome mjestu citat iz CPet (nerê po obeĉaniû obeta ne vzdati) bliži čitanju iz brevijara, točnije $\mathrm{N}_{2}$ (neže po obêĉaniû obêta ne vzdati), a da je u CGrš provedeno kraćenje teksta s ciljem snažnijega isticanja antiteze (neže obeĉavaši tr ne dati).

Ako ča obeĉal' esi g(ospod)u vzdai, ne kasni. I neugodan' est nemu neverni i bezumno obeĉanie mrzit' nemu načto obeĉaš i vzdaš. Mnogo bole est ne obeĉavaši dati neže obeçavaši tr ne dati. Ne dai ust tvoih da ne svedet' plt' tvoû eda (om.) kako prognivaet se na û e $\mathrm{B}(\mathrm{og})$ i ne pogubi vsa dela ruk tvoih, CGrš $188 \mathrm{v}$ Ako ča obeçal esi g(ospod)u vzdai ne kasni. Neugodan bo emu es(tb) nevêrni i bezumno obeĉanie da čto obeĉaši vzdai. Mnogo bole es(tb) ne obeĉavši dati nerê po obeĉaniû obeta ne vzdati. Ne dai ust' tvoih' da ne svêdêt plt tvoû ne r(e)ci pred anĵ(e)lom nest' prosmotreniê eda kako prognevaet se na te $\mathrm{B}(\mathrm{og}) \mathrm{b}$ i pogubi vsa dêla ruk' tvoih', CPet 238v

Acee čto obeĉalı esi b(og)u ne kas'ni v'zdati. Neugodan' bo emu e(stb) nevêrni i bezumno obeçanie. Nač'to lûbo obeçaši v'zdai. Mnogo bole e(stb) ne obeĉati neže po obêcaniû obêta ne vzdati. Ne dai ust' tvoihs da ne tvorets plts tvoû ni r'ci prêd' anĵ(e)li nêstb pros'motreniê eda prognêvaet' se na te b(og)b i pogubitb vsa dêla r(u)kb tvoihь, Dab 80d-81a

Acee čto obeĉalı esi b(og)u ne kasni m vzdati. Neugodan bo emu e(stb) nevêrni i bezumno obeĉanie. Načto lûbo obeĉaši v'zdai. Mnogo bole e(stb) ne obeĉati neže po obêcaniû obêta ne vzdati. Ne dai ust' tvoihs da ne tvorets pltb tvoû ni r'ci prêd' anĵ(e)li nêstı pros'motrenie eda prognêvaet se na te b(og)b i pogubitь vsa dêla ruks tvoihb, $\mathrm{N}_{2} 197 \mathrm{~cd}$

Si quid vovisti Deo ne moreris reddere displicet enim ei infidelis et stulta promissio sed quodcumque voveris redde multoque melius est non vovere quam post votum promissa non conplere ne dederis os tuum ut peccare faciat carnem tuam neque dicas coram angelo non est providentia ne forte iratus Deus super sermone tuo dissipet cuncta opera manuum tuarum, Vulgata

Usporedba Zbirke s hrvatskoglagoljskim brevijarima pokazala je kako su na više mjesta hrvatskocrkvenoslavenski oblici zamijenjeni onim starohrvatskim (boli prema luči, luč 'ši; ako prema ace ; ka prema eže; ča prema čto, izbacivanje 
veznika/čestice bo). Također je utvrđeno kako između starije i novije verzije Zbirke postoje razlike u uporabi hrvatskocrkvenoslavenskih/starohrvatskih leksema: nenavist (CCrš) / svadu (CPet); neže (CGrš) / nere (CPet); sloves (CPet) / riči (CGrš) i morfoloških oblika: budeši (CGrš) / budeš (CPet), veselit (CGrš) / veseli (CPet), miluêt (CPet) / miluê (CGrš). Količinski, najviše ostataka hrvatskocrkvenoslavenskoga nalazimo u glagolskim oblicima, pogotovo prezentskim nastavcima za 3. 1. jednine: svedokuet (CGrš CPet) / s'vedokuets (Dab, Mosk) / sv(ê)d(o)kuetb $\left(\mathrm{Vt}_{5}\right)$; poslušaet (CPet, CGrš) / poslušaetb $\left(\mathrm{N}_{2}\right.$, $\mathrm{Dab}, \mathrm{VO}) /$ poslušaet' $\left(\mathrm{Vt}_{5}\right)$; otmetaet (CPet, CGrš) / otmeçetb $\left(\mathrm{N}_{2}, \mathrm{Dab}\right) /$ otimet (VO); ispustit' (CGrš) / pustit' (CPet); vzenavidit' (CGrš, CPet, $\mathrm{N}_{2}, \mathrm{Dab}, \mathrm{Vt}_{5}$ ); budet (CGrš) / budêt' (CPet) / budetb $\left(\mathrm{N}_{2}, \mathrm{Vt}_{5}\right)$ / budêtb (Dab); sp(a) set (CPet) / $s p(a) s(e) t$ ' $\left(\mathrm{N}_{2}, \mathrm{Dab}\right) / \operatorname{sp}(a)$ set $\left(\mathrm{Vt}_{5}, \mathrm{VO}, \mathrm{Mosk}\right)$; vzlubit (CGrš) / vzlûbit'(CPet, $\mathrm{N}_{2}, \mathrm{Dab}, \mathrm{Vt}_{5}$, Mosk); êvit (CPet) / êvit $\left(\mathrm{N}_{2}, \mathrm{Vt}_{5}\right.$, Dab, $\mathrm{VO}$, Mosk).

Dok je u nekim izrekama čestica že izbačena iz citata (npr. Sin' 'mudar' veselit' oca, a sin' manen ' pečal' materi svoei, CGrš; Sin' mudar veseli o(t)ca, a sin nor ' pečali mat(e)r svoû, CPet prema S(i)nb mudar veselitb otca s(i)nb že bez'uman pečalb e(st) materi svoei $\mathrm{N}_{2}$ 194b; $S(i) n b$ mud(a)rb veselitb o(t)ca s(i)n že bezumbn ' pečalb materê svoei VO 358a; Sinb mudrb vesel(i)tb o(tb)ca s(i)n že bezum(b)nь pečalb $m(a) t\left(\right.$ ) rê svoei, $\mathrm{Vt}_{5} 175 \mathrm{~d}$ ), na nekim mjestima se ona čuva: srce že norih' (CGrš, CPet) prema s'rce že norihb (Mosk). U CGrš nešto je više ikaviziranih oblika: korijenskih (gniv, vinac, riči, starišinu, diticêm), ali i gramatičkih (kadi). No, unatoč višekratnom zamjenjivanju hrvatskocrkvenoslavenskih leksema onim hrvatskim, sličnost citata iz Zbirke s onima iz glagoljskih brevijara nipošto nije zanemariva. Uz to što je utvrđeno postojanje istih hrvatskocrkvenoslavenskih oblika, u ovome je kontekstu bitno još jednom istaknuti veliku podudarnost između citata u Zbirci i citata u brevijarima u kojima su sačuvane dulje lekcije mudrosnih knjiga. S obzirom na to da je srednjovjekovna kultura bila uvelike pamćenjska možemo pretpostaviti kako je neke izreke kompilator/pisar prenosio prema sjećanju. ${ }^{70}$ Drugim riječima, Zbirka moralnih sentencija vjerojatno je dijelom, neovisno o tome je li riječ o izravnom prepisivanju ili pamćenju nekad pročitanoga teksta, nastala prema brevijarskim lekcijama. Dakako, ostaje mogućnost da su brevijarske lekcije i Zbirka imale isti, nama danas nepoznati, izvor kada je riječ o citatima iz mudrosnih knjiga.

\section{Zaključak}

U kontekstu hrvatskoglagoljske književnosti Zbirka sentencija predstavlja najsažetiju vrstu refleksivne poučne proze. Unatoč svojoj relativnoj kratkoći, te

${ }^{70}$ Vidi M.-A. DÜRRIGL, 2019, 674. 
izostanku duljih objašnjenja i tumačenja koja nalazimo u drugim refleksivnim tekstovima, u njoj se ocrtavaju vrijedni savjeti u ispravan mudar život, od kojih su neki vjerojatno inspirirani čitanjem glagoljaške lektire. Pojedine sličnosti citata iz mudrosnih knjiga s nekim hrvatskoglagoljskim brevijarima (ponajviše $\mathrm{s} \mathrm{N}_{2} \mathrm{i} \mathrm{Vt}$ ), a pogotovo one koje ne nalazimo u grčkim i latinskim izvorima, osnažuju pretpostavku o mogućem zagledanju u liturgijske knjige (ili možda pamćenju dijela njihova sadržaja) tijekom prepisivanja teksta. Neke grafičke osobitosti iz starijega Petrisova zbornika daju naslutiti kako je Zbirka nastala iz opsežnijeg florilegija iz kojega je glagoljaš kompilirao tekst. Također, redoslijed pojavljivanja citata i parafraza, pokazuje kako nije riječ o nepovezanu nizanju citata, nego da se u kratkom tekstu može pronaći više manjih cjelina, od kojih se neke izdvajaju i na stilsko-sintaktičkoj razini (povezivanjem citata sintaktičkim paralelizmima ili anaforama).

Zbirkaje najkraći dosad poznati tekst hrvatskoglagoljske refleksivne proze, ujedno još jedna potvrda mouvancea u glagoljskim zbornicima tijekom kojega se pojedini tekst ujedinjuje s drugim poprimajući svojevrsnu novu funkciju.

\section{Literatura}

\section{Izvori}

Ber $_{2}$ - Drugi beramski brevijar, 15. st., Ljubljana, Narodna in univerzitetna knjižnica, sign. Ms 163.

CGrš - Grškovićev zbornik, 16. st., Arhiv HAZU, sign. VII 32.

CPet - Petrisov zbornik, 1468., NSK, sign. 4001.

Dab - Dabarski brevijar, 1486., Arhiv HAZU, sign. III c 21.

Mavr-Mavrov brevijar, 1460., NSK, sign. 7822.

Mosk - Moskovski brevijar, oko 1442.-1443., Moskva, Rossijskaja gosudarstvennaja biblioteka, Zbirka Sevastyanov, sign. Fond 270, 51.

$\mathrm{N}_{1}$ - Prvi novljanski brevijar, 1459., Novi Vinodolski, Župni ured.

$\mathrm{N}_{2}$ - Drugi novljanski brevijar, 1495., Novi Vinodolski, Župni ured

Pad - Padovanski brevijar, sredina 14. st., Padova, Biblioteca Universitaria Bologna, sign. 2282

$\mathrm{Vb}_{1}$ - Prvi vrbnički brevijar, 13./14. st., Vrbnik, Župni ured

$\mathrm{Vb}_{2}$ - Drugi vrbnički brevijar, 14. st., Vrbnik, Župni ured

$\mathrm{Vb}_{3}$ - Treći vrbnički brevijar, 15. st., Vrbnik, Župni ured

VO - Brevijar Vida Omišljanina, 1396., Beč, Österreichische Nationalbibliothek, sign. Cod. slav. 3

$\mathrm{Vt}_{5}$ - Peti vatikanski brevijar, sredina 14. st., Biblioteca Apostolica Vaticana, sign. Borg. Illir. 5. 


\section{Knjige $i$ članci}

Ivan BAKMAZ, Biblijska čitanja u hrvatskoglagoljskim brevijarima, u: Marija-Ana DÜRRIGL - Milan MIHALJEVIĆ - Franjo VELČIĆ (ur.), Glagoljica i hrvatski glagolizam. Zbornik radova s međunarodnoga znanstvenog skupa povodom 100. obljetnice Staroslavenske akademije i 50. obljetnice Staroslavenskoga instituta (2. - 6. listopada 2002.), Staroslavenski institut - Krčka biskupija, Zagreb - Krk, 2004, 139-148.

Vaclav ČERMÁK, Proverbia v charvátskohlaholských breviářích a jejichne slovanské předlohy, Slavia, 68, 1999, 251-258.

Vaclav ČERMÁK, Starozákonni mudroslovné knihy v charvátskohlaholskych breviáŕích (Textologická analyza Proverbií), Univerzita Karlova v Praze, Filozofická fakulta, Ústav slavistickych a vychodoevropskych studií, 2001.

Vaclav ČERMÁK, Historický přehled zkoumán ístarozákonních perikop charvátskohlaholských breviárưu, u: Marija-Ana DÜRRIGL-Milan MIHALJEVIĆ - Franjo VELČIĆ (ur.), Glagoljica i hrvatski glagolizam. Zbornik radova s međunarodnoga znanstvenog skupa povodom 100. obljetnice Staroslavenske akademije i 50. obljetnice Staroslavenskoga instituta (2. - 6. listopada 2002.), Staroslavenski institut - Krčka biskupija, Zagreb - Krk, 2004, 149-155.

Vaclav ČERMÁK, K nekotorym osobenost'am členenija slav'anskogo perevoda Knigi Pritč v rukopisi F. I. 461, Kirilo-Metodievski studii, 17, 2007, 827-831.

Gilbert DAHAN, The Sapiental Books in the Latin Middle Ages, u: Samuel L. ADAMS - Matthew J. GOFF (ur.), The Wiley Blackwell Companion to Wisdom Literature, Hoboken, NJ Wiley Blackwell, 2020, 429-446.

Marija-Ana DÜRRIGL, O čitanju, pisanju i kompiliranju u hrvatskoglagoljskom srednjovjekovlju, Slovo, 60, Zagreb, 2010, 219-234.

Marija-Ana DÜRRIGL, Razgovor duše i misli - između prenja, propovjednosti i meditacije, Slovo, 61, Zagreb, 2011, 40-63.

Marija-Ana DÜRRIGL, Motiv posta i molitve u hrvatskoglagoljskim tekstovima 15. i 16. stoljeća, Diacovensia, 27/4, Đakovo, 2019, 671-687.

Dunja FALIŠEVAC, Hrvatska srednjovjekovna proza. Književnopovijesne i poetičke osobine, Sveučilišna naklada Liber, Zagreb, 1980.

Gabriel FORD, Framing, Parataxis, and the Poetics of Exemplarity in Petrus Alfonsi's Disciplina Clericalis, Medieval Encounters, 21, 2015, 26-49.

Dolores GRMAČA, Književnopovijesna dimenzija Libra, u: Mateo ŽAGAR (prir.), Libro od mnozijeh razloga. Latinički prijepis s komentarima, Matica hrvatska, Zagreb, 2020, 36-60.

Richard L. HARRIS, Some Paroemiological Approaches to Studies in North Germanic Medieval Literatures and Cultures, u: Michael CICHON - Yin LIU (ur.), Proverbia Septentrionalia. Essays on Proverbs in Medieval Scandinavian and English Literature, 2019, 9-21.

Richard HAZELTON, The Christianization of "Cato": The Disticha Catonis In the Light of Late Mediaeval Commentaries, Mediaeval studies, 19, 1957, 157-173. 
Eduard HERCIGONJA, Povijest hrvatske književnosti: srednjovjekovna književnost, knj. 2, Liber-Mladost, Zagreb, 1975.

Hrvatska srednjovjekovna proza, knj. 2, Apokrifi, vizije, prenja, Marijini mirakuli, Stoljeća hrvatske književnosti, sv. 116, Priredila i transkribirala Marija-Ana DÜRRIGL, Matica hrvatska, Zagreb, 2013.

Antonija ZARADIJA KIŠ, Knjiga o Jobu u hrvatskoglagoljskoj književnosti, Matica hrvatska i Hrvatsko filološko društvo, Zagreb, 1997.

Antonija ZARADIJA KIŠ, Mudrosne knjige hrvatskoga srednjovjekovlja, u: Prvi hrvatski slavistički kongres. Zbornik radova I, Zagreb, Hrvatsko filološko društvo, 1997, 629-635.

Antonija ZARADIJA KIŠ - Marinka ŠIMIĆ, Cvijet kreposti ili o naravi ljudskoj kroz narav životinjsku. Sudija - transliteracija - faksimil, Hrvatska sveučilišna naklada, Institut za etnologiju i folkloristiku, Staroslavenski institut, Zagreb, 2020.

Pavao KNEZOVIĆ, Rimski pisci u Cvitu, u: Pavao KNEZOVIĆ - Marinko ŠIŠAK - Milivoj ZENIĆ (ur.), Zbornik o Pavlu Posiloviću, Gradska knjižnica "Juraj Šižgorić" Šibenik, Hrvatski studiji, Šibenik - Zagreb, 2001, 17-52.

Bratislav LUČIN, Kojoj književnosti pripadaju Dobri nauci?, Colloquia Maruliana, 8, Split, 1999, 65-80.

Marko MARULIĆ, Pisni razlike, priredio i popratio bilješkama Josip Vončina, rječnik sastavio Milan Moguš, Split, 1993 (Sabrana djela Marka Marulića, Knjiga druga).

Franjo MAXINER, Prievodi t. z. "Disiticha moralia Catonis" u hrvatskoj literaturi, $R A D$ JAZU, 74, Zagreb, 1885, 79-134.

Irena MILIČIĆ, Starozavjetna knjiga mudrosti u hrvatskoglagoljskim brevijarima, Slovo, 47-49, Zagreb, 1999, 57-112.

Andrea RADOŠEVIĆ, Vele lipo i korisno kompiliranje - Liber de modo bene vivendi ad sororem u Grškovićevu zborniku iz 16. stoljeća, Croatica, 61, Zagreb, 2017, 43-72.

Andrea RADOŠEVIĆ - Marija-Ana DÜRRIGL, Glagoljska čitateljska zajednica na primjeru Drugoga beramskoga brevijara, Slovo, 70, Zagreb, 2020, 191-216.

Johannes REINHART, The Sapiental Collection in the Croatian Glagolitic Missal, Proceedings of the World Congress of Jewish Studies. Jewish Languages, other languages, 1985, 77-84.

Johannes REINHART, Kombinacija dvaju mirakula u hrvatskoglagoljskom rukopisu (Grškovićev zbornik, HAZU VII 32), Slovo, 60, Zagreb, 2010, 669-686.

Johannes REINHART, Nauk sinu Vičerdovu u hrvatskoglagoljskoj književnosti, Slovo, 62, Zagreb, 2012, 211-232.

Vesna BADURINA STIPČEVIĆ, Tobija, Judita i Estera u hrvatskoglagoljskim brevijarima, Književna smotra, 92-94, Zagreb, 1994, 209-212.

Vesna BADURINA STIPČEVIĆ, Later Croato-Glagolitic Biblical Translations, Journal of Croatian studies, 36-37, 1996, 53-62. 
Vesna BADURINA STIPČEVIĆ, Hrvatskoglagoljska Biblija, u: Marijan VUGDELIJA (ur.), Biblija - knjiga Mediterana par excellence (Zbornik radova s međunarodnog znanstvenog skupa održanog od 24. do 26. rujna 2007. u Splitu), Književni krug, Split, 2010, $383-398$.

Vesna BADURINA STIPČEVIĆ, Priča o premudrom Akiru u hrvatskoglagoljskom Petrisovu zborniku (1468), u: V. BADURINA STIPČEVIĆ - SANDRA POŽAR - FRANJO VELČIĆ (ur.), Hrvatsko glagoljaštvo u europskom okružju, Staroslavenski institut, Zagreb, 2015, 379-398.

VesnaBADURINASTIPČEVIĆ, Nahtigalovatekstološkaistraživanjahrvatskoglagoljskih biblijskih knjiga, u: Petra STANKOWSKA - Aleksandra DERGANC - Alenka ŠIVIC-DULAR (ur.), Rajko Nahtigal in 100 let slavistike na Univerzi v Ljubljani, Slavica Slovenica, Ljubljana, 2019, 153-161.

Vjekoslav ŠTEFANIĆ, Glagoljski rukopisi otoka Krka, Djela JAZU, knj. 51, JAZU, Zagreb, 1960.

Искра ХРИСТОВА-ШОМОВА, Притчи Соломонови във Втория берамски бревиар, Slovo, 71, Zagreb, 2021, 17-56.

Barry TAYLOR, Medieval Proverb Collections: The West European Tradition, Journal of the Warburg and Courtauld Institutes, 55, 1992, 19-35.

Al WOLTERS, Proverbs. A Commentary based on Paroimiai in Codex Vaticanus, Leiden - Boston Brill, 2020.

\section{Internetski izvori}

VULGATA, SEPTUAGINTA, URL: https://www.academic-bible.com/en/online-bibles/ about-the-online-bibles/ (2021-8-31)

\section{A COLLECTION OF MAXIMS FROM PETRIS'S AND GRŠKOVIĆ'S MISCELLANIES IN THE CONTEXT OF CROATIAN GLAGOLITIC REFLECTIVE PROSE}

\section{Summary}

A short collection of maxims from two Croatian Glagolitic miscellanies is analysed in the paper: Petris's and Gršković's. The collection consists mostly of quotations and paraphrases of biblical books of wisdom (Proverbs, Ecclesiastes, Book of Sirach). With the comparison of two transcripts of the Collection from the mentioned collections with Croatian Glagolitic breviaries, the similarities and differences in the approach to biblical quotations are determined. The confirmation of a free relationship towards the transcribed text can be found in several examples, especially in the compilation from the $16^{\text {th }}$ century. The similarities between the quotations in the Collection and some breviaries, and which we find neither in the Septuagint, nor in the Vulgate, nor in the Prophetologions, point to the possibility of the use of Glagolitic breviaries during the transcribing of the Collection. The paper contributes to the knowledge of Croatian mediaeval reflective prose.

Keywords: mediaeval reflective prose, books of wisdom, collection of maxims, Petris's Miscellany, Gršković's Miscellany 